Leptochloa Fusca Cultivation for Utilization of Salt - affected Soil and Water Resources in Cholistan Desert

Farooq Ahmad

\title{
LEPTOCHLOA FUSCA CULTIVATION FOR UTILIZATION OF SALT - AFFECTED SOIL AND WATER RESOURCES IN CHOLISTAN DESERT
}

\author{
Cultivo de Leptochloa Fusca para a utilização de solos afetados por \\ sais e recursos hídricos no Deserto de Cholistan
}

Farooq Ahmad

Department of Geography, University of the Punjab

Lahore, PAKISTAN

farooq@geog.pu.edu.pk

Artigo recebido para publicação em 15/07/2009 e aceito para publicação em 08/02/2010

ABSTRACT: In the Cholistan Desert, 0.44 million hectares are salt - affected low lying and clayey in nature locally known as 'dhars', where rainwater as well as saline groundwater could be utilized for growing salt tolerant grasses like Leptochloa fusca as forage during summer. L. fusca is a promising candidate grass for economic utilization and better management of sodic, high $\mathrm{pH}$, saline soil and saline water resources of the Cholistan desert. L. fusca is known to be a versatile, halophytic, primary colonizer, easily propagatable, perennial, nutritive and palatable forage plant species. The grass has the good biomass producing potential and can grow equally well both under upland and submerged saline soil environment.

Keywords: Cholistan, Leptochloa fusca. Saline irrigation. Salt - affected. Soil reclamation.

RESUMO: $\quad$ No Deserto de Cholistan, 0,44 milhões de hectares são afetados por condições de solos rasos, salinos e argilosos por natureza, sendo localmente conhecidos como 'dhars', onde a água da chuva, bem como as águas subterrâneas salinas poderiam ser utilizadas para o cultivo de gramíneas tolerantes a sais, como a Leptochloa fusca, como forragem durante o verão. A L. fusca é uma gramínea promissora para a utilização econômica e melhor manejo dos solos salinos, sódicos e com alto pH e dos recursos hídricos salinos do Deserto de Cholistan. A gramínea é conhecida por ser versátil, halófila, colonizadora primária, de fácil propagação, perene, nutritiva e por ser uma espécie de planta forrageira palatável. Além disso, possui um bom potencial de produção de biomassa e pode crescer igualmente tanto em ambientes de sequeiro quanto em ambientes de solos salinos inundáveis.

Palavras - Chave: Cholistan. Leptochloa fusca. Irrigação salina. Solos afetados por sais. Recuperação de solos degradados.

\section{INTRODUCTION}

The Cholistan Desert (FIGURE 1) lies within the southeast quadrant of Punjab Province between $27^{\circ} 42^{\prime}$ and $29^{\circ} 45^{\prime}$ North latitude and $69^{\circ} 52^{\prime}$ and $73^{\circ}$

05' East longitude (FAO/ADB 1993; ARSHAD et al. 1995; JOWKAR et al. 1996; AHMAD et al. 2004; AHMAD 2005; 2007; 2008) and covers an area of 2.6 
million hectares (AHMAD 2002), out of which 1.13 million ha comprising stable as well as non - stable sand dunes, 0.95 and 0.06 million ha consist of sandy and loamy soils respectively, while 0.44 million ha are clayey in nature, locally known as 'dhars'. About $17 \%$ of Cholistan consist of such 'dhars' (TABLE 1) having flat and hard surface with salt incrustation and surrounded by sand dunes. Dhars are shallow to moderately deep, poorly drained with low vegetation, calcareous and having saline sodic fine to medium textured clayey soils. Except Haloxylon recurvum, other plant species can't survive due to salinity, compaction of soil and complete inundation during rainy season. The ponded rainwater in 'dhars' stagnates for a period until the water evaporates (KHAN et al., 1990). It is judicious to utilize the land using ground saline and surface rainwater resources for growing palatable grasses. Biological approach for economic utilization of salt - affected soil are feasible and is the only viable method when the soil is sodic and sweet water is unavailable for irrigation (ABDULLAH, 1985).

Leptochloa fusca is highly tolerant of saline and sodic conditions even when irrigated by saline groundwater or ponded rainwater. After the successful cultivation of L. fusca in Cholistan, other palatable grasses like para grass (Brichiaria mutica), Rhodes grass (Chloris gayana), Bermuda grass (Cynodon dactylon) and Sporobolus grass species can be tested (ABDULLAH et al. 1990). The cultivation of salt tolerant grasses would not only provide much needed palatable forage for livestock but also improve the soil physical properties due to biological activity of grass roots.

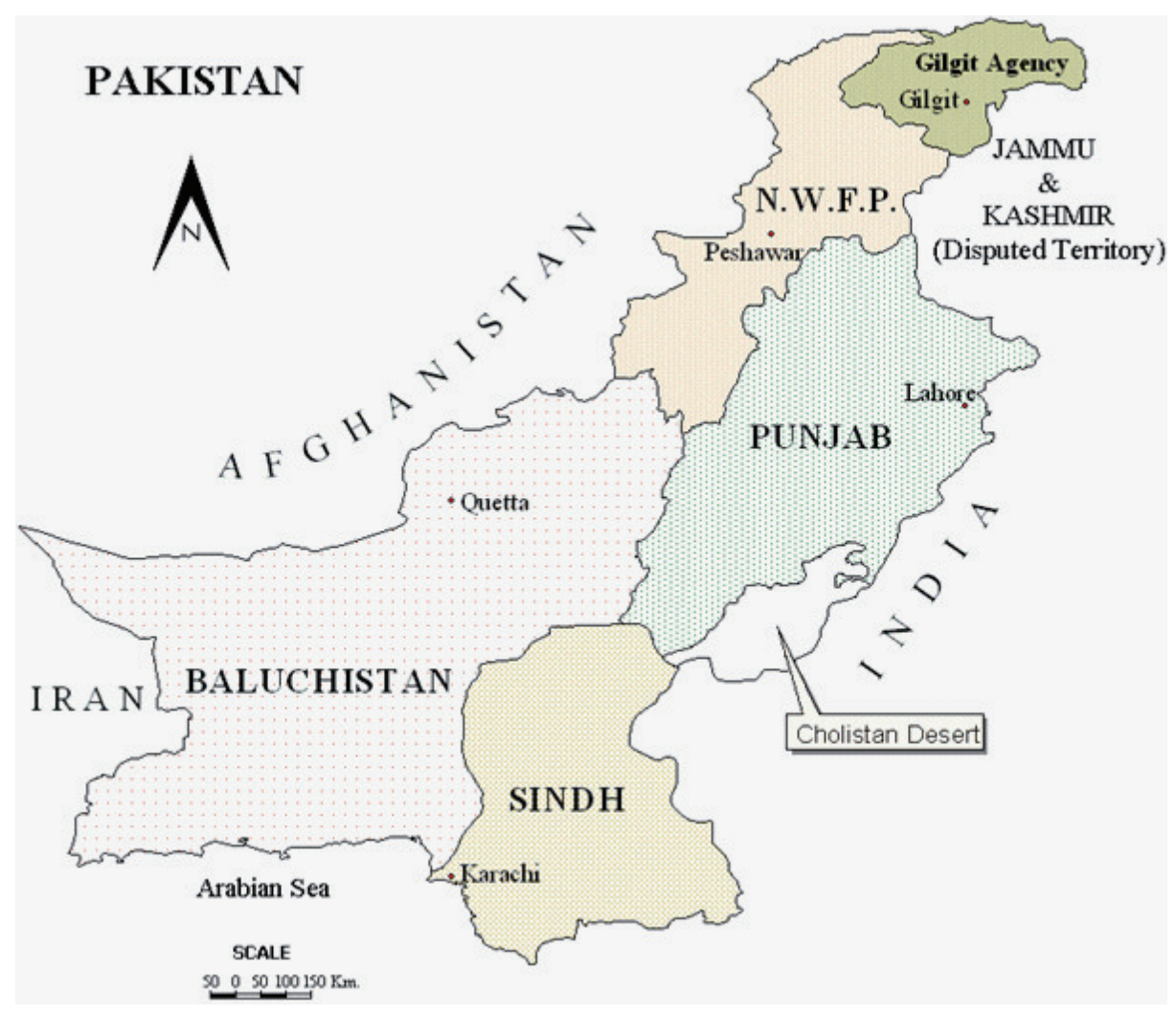

FIGURE 1: Location map of Cholistan desert 
TABLE 1: Soil Types

\begin{tabular}{|c|c|c|}
\hline Soil Types & Extent $(\mathrm{Ha})$ & Percentage \\
\hline Sand dunes & $1,133,900$ & 44.0 \\
\hline Sandy soils & 945,500 & 37.0 \\
\hline Loamy soils & 58,700 & 2.0 \\
\hline Saline sodic clayey soils (Dhars) & 441,900 & 17.0 \\
\hline Total & $2,580,000$ & 100.0 \\
\hline
\end{tabular}

Source: PADMU. - Pakistan Desertification Monitoring Unit.

\section{GROWTH CHARACTERISTICS OF LEPTOCHLOA FUSCA}

Leptochloa fusca is also known as Diplachne fusca, and is widely spread in salt affected regions of Pakistan. This forage plant is locally known as "Kallar grass" (salt grass). Being a tropical grass, the plant follows the photosynthetic $\mathrm{CO}_{2}$ fixation process of $\mathrm{C}_{4}$ - NAD - malice enzyme metabolism (Zafar and Malik 1984). It is native of saline soil which gives clear indication of its halophytic character; the plant is perennial or biennial in nature. It has been regarded as good quality forage especially in salt affected and waterlogged areas where other superior forage species may not grow successfully.

Leptochloafusca can be easily propagated and established through seed, stem cutting, root stumps or rhizomes. The grass can grow to a height of $1-1.5$ meters with a high leaf production rate and can be grazed directly or cut for stall - feeding. This fodder is highly palatable to sheep, goats, buffaloes and cattle alike and no toxic effects of this grass during long term consumption have been diagnosed. Moreover, it is similar to other conventional fodder regarding its nutritional status and $3-4$ cutting within 3 months may be easily harvested, producing $20-40$ tonnes of green fodder per ha per year or $5-10$ tonnes per ha per cutting in salt - affected soils (SANDHU et al. 1981; QURESHI et al. 1982; SANDHU 1993). The grass grows well during the hot season from March to September with peak yields during rainy season i.e. July and August in Pakistan, indicating a strongly thermophilic character. The development of extensive and dense fibrous root system has been observed even in highly sodic soils (JOSHI et al.
1981). The penetration of roots in such soils can enhance hydraulic conductivity, microbial activity, organic matter and ultimately leaching of salts. This grass can make better growth under normal situation than under stress conditions, but it is a common observation that, in normal soils, the grass could not compete with other species and is soon eliminated due to the growth of other vegetation. Joshi et al (1981) noted a decline of $L$. fusca growth due to decrease of soil sodicity, while Haq and Khan (1971) observed that L. fusca has a general tendency to decrease $\mathrm{EC}_{\mathrm{e}}$ (electrolyte conductivity), SAR (sodium adsorption ratio), $\mathrm{pH}$ (soluble ions) and even ESP (exchangeable sodium percentage) of artificially salinized soils. Malik et al. (1986) confirmed the utility of L. fusca not only as a primary colonizer of salt - affected lands, but also as ameliorative plant for the soil.

\section{NUTRITIONAL REQUIREMENTS}

It has been observed that $3-4$ cuttings of this grass could be easily taken without the addition of nitrogen $(\mathrm{N})$ fertilizer in salt - affected and less fertile soils. Malik et al. (1980) demonstrated a high activity of $\mathrm{N}$, which indicates strong associative symbiotic relationship of $\mathrm{N}_{2}$ - fixing bacterium (Bacillus gram negative) in the rhizosphere of $L$. fusca. Moreover, the $\mathrm{N}$ fixation through the growth of blue - green algae and Azolla under flooded conditions may partly contribute to the $\mathrm{N}$ supply and economy of the species. It is also observed that $L$. fusca contributes more stable organic matter fraction due to its slow decomposition as compared to succulent plant species like Sesbania aculeata. Kumar et al. (1980) reported an abrupt increase in the yield of $L$. fusca from $24-26$ tonnes per ha per year, 
Leptochloa Fusca Cultivation for Utilization of Salt - affected Soil and Water Resources in Cholistan Desert Farooq Ahmad

without $\mathrm{N}$ application to $41-46$ tonnes per ha per year when only $40 \mathrm{~kg} \mathrm{~N}$ per ha was applied in a sodic soil. Abdullah (1985) showed a definite ameliorative effect of phosphorus (P) on the growth of L. fusca under saline environment. The application of $\mathrm{P}$ at the rate of $50 \mathrm{~kg}$ per ha gave significantly higher fresh and dry matter yield at $\mathrm{EC}_{\mathrm{e}} 10 \mathrm{dS} \mathrm{m}^{-1}$ than all other treatments, which was followed by 75 and $25 \mathrm{~kg} \mathrm{P}$ per ha at $\mathrm{EC}_{\mathrm{e}} 20 \mathrm{dS} \mathrm{m}^{-1}$. The synergistic $\mathrm{P}^{\prime}$ salinity effect was obvious at the highest P level of $75 \mathrm{~kg}$ per ha. Thus, the species responded favourably to $\mathrm{P}$ application at all salinity levels studied (i.e. $\mathrm{EC}_{\mathrm{e}} 3.5$ to $30 \mathrm{dS} \mathrm{m}^{-1)}$, indicating higher $\mathrm{P}$ requirements. In general, the species is capable of accumulate trace elements $(\mathrm{Zn}, \mathrm{Cu}, \mathrm{Fe}, \mathrm{Mn})$ in sufficient amounts to meet the dietary requirements of the livestock under saline soil conditions (Abdullah et al. 1990).

\section{ROLE IN SOIL RECLAMATION}

Leptochloa fusca behaved as a typical Crypno - eu - halophyte having both accumulating and excreting properties (Abdullah 1986; Abdullah et al. 1990). The efficient salt excretion from the shoot makes it a useful plant to deplete excessive salt from the root - zone and to provide a better root - environment for the growth of other plants. The extensive and fibrous roots of grass can open soil, increase air exchange, organic matter and hydraulic conductivity, decrease rhizosphere $\mathrm{pH}$, stimulate biological activity, dissolve native $\mathrm{CaCO}_{3}$, enhance leaching of salts, lower the water table of waterlogged soils, release plant nutrients and the shoot foliage can increase organic matter, humus and soil mulching, decrease surface evaporation and progressively improve soil physical propertiese (HAQ and KHAN 1971; JOSHI et al. 1981; ABDULLAH et al. 1986; MALIK et al. 1986 and AKHTAR et al. 1988).

\section{USE OF GROUND SALINE WATER FOR IRRIGATION}

Although the groundwater is saline, it can be used for saline agriculture to grow salt tolerant trees, vegetables, crops and fodder grasses in non - saline - non - sodic coarse textured soils with minimum adverse effects. This is due to rapid leaching of salts beyond the root zone and flushing of salts from root zone by rains (ABDULLAH et al. 1990). Furthermore, dense saline - sodic soils can also be used for growing such palatable grasses, which are very salt tolerant and capable of surviving in soils with poor properties. The sandy and loamy soil that is about 1 million ha can be brought under agriculture by using underground saline water and harvested rainwater. Experiments showed that under certain conditions plant could not only survive but also even vast areas of land could be irrigated with water of such high concentration. The soil is either sandy gravel or dune sand. Moderately saline irrigation water stimulates vegetation, assists the benevolent bacteria of the soil and improves yield and quality. Furthermore, use of brackish water reduces soil evaporation, transpiration of plants and increases resistance to drought (ABDULLAH et al. 1990). The solution of the adverse effects is suggested:

- Identification and selection of species and varieties tolerant of high salinity,

- The use of brackish water of such a degree of salinity only as is compatible with help of such species and with the nature of the soil,

- The selection of irrigation with such water in areas in which soils permeable, well drained and rich in calcium and the hydrates of iron and aluminium.

The Pakistan Council of Research in Water Resources (PCRWR) has planted Eucalyptus, Acacia, Parkinsona, Zizyphus (Beri), Tamarix, Prosopis, Asparagus, Date palm, Pomegranate, Jojoba and Iple Iple (Leucaena leucocephala). The saline water of concentration TSS (total soluble salts) is 2800 ppm (part per million) and SAR (sodium adsorption ratio) is 14 and being used for irrigation along with harvested rainwater to flush salts at certain intervals (Abdullah et al. 1990). The calcium sulphate fertilizer is also used to neutral the adverse effects of sodium salts. The growth of some of them is given in TABLES 2, 3 and 4. 
Leptochloa Fusca Cultivation for Utilization of Salt - affected Soil and Water Resources in Cholistan Desert Farooq Ahmad

TABLE 2: Biomass of fodder grasses per hectare grown at Dingarh, Cholistan Desert using saline water

\begin{tabular}{|l|c|c|c|c|c|c|}
\hline \multirow{2}{*}{\multicolumn{1}{c}{ Fodder grass }} & \multirow{2}{*}{$\begin{array}{c}\text { Biomass } \\
\text { Fresh (kg) }\end{array}$} & \multirow{2}{*}{$\begin{array}{c}\text { Biomass } \\
\text { Dry }(\mathrm{kg})\end{array}$} & & \multicolumn{4}{c|}{ Carrying capacity per year } \\
\cline { 5 - 8 } & & & Camel & Goat & Sheep & \multirow{2}{*}{ Cattle } \\
\hline Cenchrus ciliaris & 16811 & 15012 & 2 & 14 & 16 & 3 \\
\hline Panicum antidotale & 22191 & 12407 & 1 & 11 & 14 & 3 \\
\hline Lasirus sindicus & 25217 & 18247 & 2 & 17 & 20 & 4 \\
\hline Napier Bajra & 43710 & 38780 & 4 & 35 & 42 & 9 \\
\hline Leptochloa fusca & 13449 & 11445 & 1 & 10 & 13 & 3 \\
\hline
\end{tabular}

Forage requirement (Dry matter per day):

1 sheep $=2.5 \mathrm{~K}$

1 goat $=3.0 \mathrm{~K}$

$1 \mathrm{camel}=25.0 \mathrm{~K}$

1 cattle $=12.5 \mathrm{~K}$

Source: Based on field survey, June 2000.

TABLE 3: Biomass potential of some salt tolerant forages

\begin{tabular}{|l|c|c|c|c|c|}
\hline Species & $\begin{array}{c}\text { Green matter } \\
\text { (kg/plant) }\end{array}$ & $\begin{array}{c}\text { Dry matter (kg/ } \\
\text { plant) }\end{array}$ & $\begin{array}{c}\text { Green matter yield } \\
\text { (tonnes/hec) }\end{array}$ & $\begin{array}{c}\text { Dry matter yield } \\
\text { (tonnes/hec) }\end{array}$ & Plants/hec \\
\hline Atriplex amnicola 949 & 4.31 & 1.99 & 2.7 & 1.24 & 625 \\
\hline Atriplex amnicola 971 & 5.37 & 2.39 & 3.4 & 1.49 & 625 \\
\hline Atriplex amnicola 573 & 6.73 & 3.43 & 4.2 & 2.14 & 625 \\
\hline $\begin{array}{l}\text { Atriplex amnicola } \\
\square \text { Atriplex nummularia }\end{array}$ & 5.13 & 2.15 & 3.2 & 1.34 & 625 \\
\hline $\begin{array}{l}\text { Atriplex buburyana 1205 } \\
\text { Carnarvan) }\end{array}$ & 3.11 & 1.6 & 7.8 & 4.0 & 2500 \\
\hline Atriplex buburyana 1200 (Leonora) & 2.0 & 1.2 & 5.0 & 3.0 & 2500 \\
\hline Atriplex cinerea 524 & 5.0 & 2.35 & 3.1 & 1.46 & 625 \\
\hline Atriplex lentoformis & 5.45 & 3.19 & 3.4 & 2.0 & 625 \\
\hline Maireana aphylla 1062 & 2.53 & 1.2 & 6.3 & 3.0 & 2500 \\
\hline
\end{tabular}

Source: PADMU. - Pakistan Desertification Monitoring Unit (1986).

TABLE 4: Survival percentage and canopy cover of some plants grown in Cholistan Desert

\begin{tabular}{|c|c|c|c|c|c|c|c|c|}
\hline \multirow{2}{*}{ Name of Tree / Shrub / Bush } & \multirow[t]{2}{*}{$\begin{array}{c}\text { Age } \\
\text { (months) }\end{array}$} & \multirow{2}{*}{$\begin{array}{c}\text { Survival } \\
\text { Percentage }\end{array}$} & \multicolumn{3}{|c|}{ Height (Cm) } & \multicolumn{3}{|c|}{ Canopy Cover $(\mathrm{Cm})$} \\
\hline & & & Min. & Mean & Max. & Min. & Mean & Max. \\
\hline Eucalyptus (Camddulensis) & 24 & 76 & 90 & 156 & 223 & 66 & 113 & 161 \\
\hline Tamarix & 24 & 48 & 59 & 106 & 154 & 52 & 112 & 173 \\
\hline Acacia & 24 & 67 & 66 & 125 & 193 & 55 & 126 & 197 \\
\hline Beri (Zizyphus) & 24 & 43 & 55 & 118 & 181 & 38 & 82 & 126 \\
\hline Jojoba (Simmondsia chinensis) & 18 & 76 & 20 & 60 & 110 & 08 & 48 & 89 \\
\hline Atriplex halimus (Local) & 11 & 65 & -- & 77 & --- & -- & 45 & --- \\
\hline Atriplex amnicola 573 & 11 & 40 & -- & 48 & --- & -- & 08 & --- \\
\hline Atriplex amnicola 197 & 11 & 80 & -- & 74 & --- & -- & 15 & --- \\
\hline Atriplex amnicola 223 & 11 & 25 & -- & 47 & --- & -- & 09 & --- \\
\hline Atriplex bunburyana 1041 & 11 & 60 & -- & 51 & --- & -- & 07 & --- \\
\hline Atriplex bunburyana 1036 & 11 & 70 & -- & 66 & --- & -- & 13 & --- \\
\hline Atriplex cincerea & 11 & 40 & -- & 28 & --- & -- & 02 & --- \\
\hline Atriplex lintiformis & 11 & 60 & -- & 76 & --- & -- & 26 & --- \\
\hline Atriplex commercial & 11 & 25 & -- & 44 & --- & -- & 13 & --- \\
\hline Maireana aphylea & 11 & 85 & -- & 35 & --- & -- & 30 & --- \\
\hline
\end{tabular}

Source: PADMU. - Pakistan Desertification Monitoring Unit (1986). 
Leptochloa Fusca Cultivation for Utilization of Salt - affected Soil and Water Resources in Cholistan Desert Farooq Ahmad

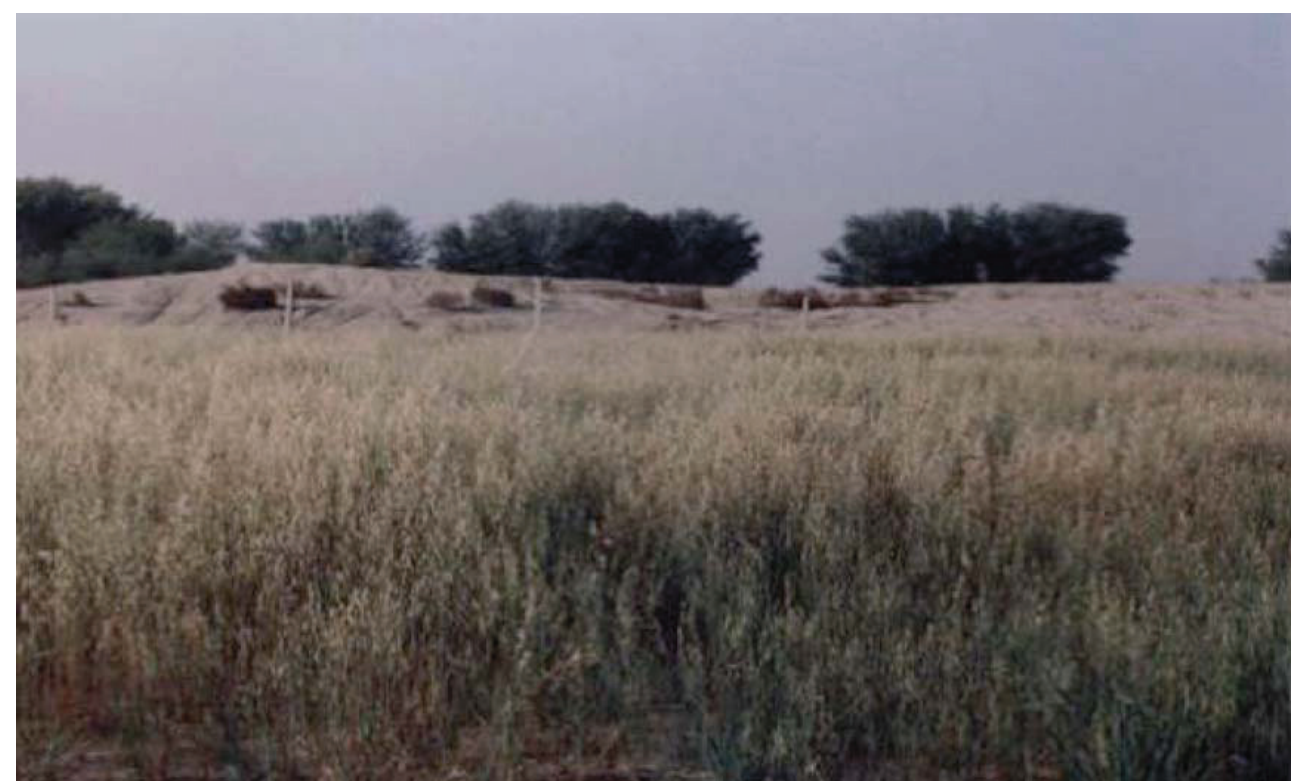

FIGURE 2: Wild oats grown by highly saline irrigation at PCRWR research station at Cholistan desert (Pakistan). Ahmad, Farooq 2008.

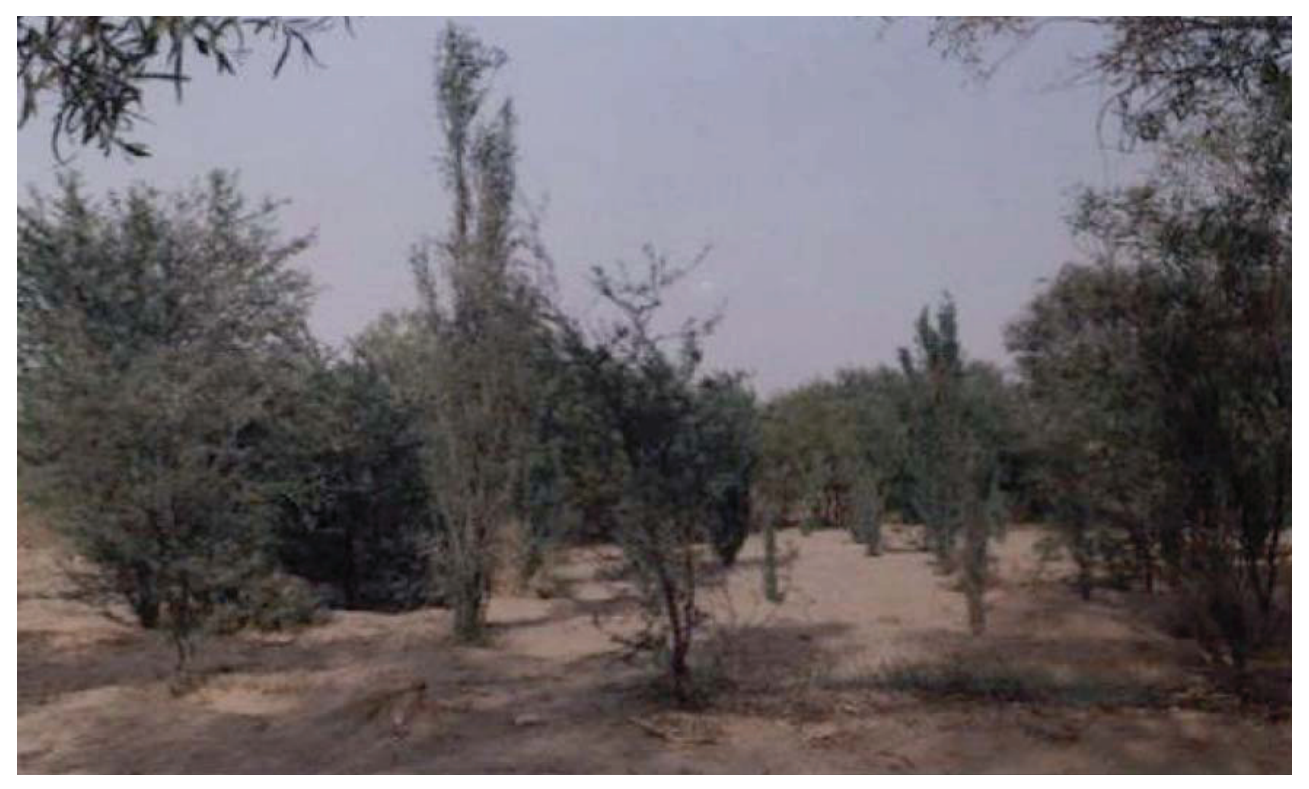

FIGURE 3: Frost trees grown by highly saline irrigation at PCRWR research station at Cholistan desert (Pakistan). Ahmad, Farooq 2008.

Sociedade \& Natureza, Uberlândia, 22 (1): 141-149, abr. 2010 


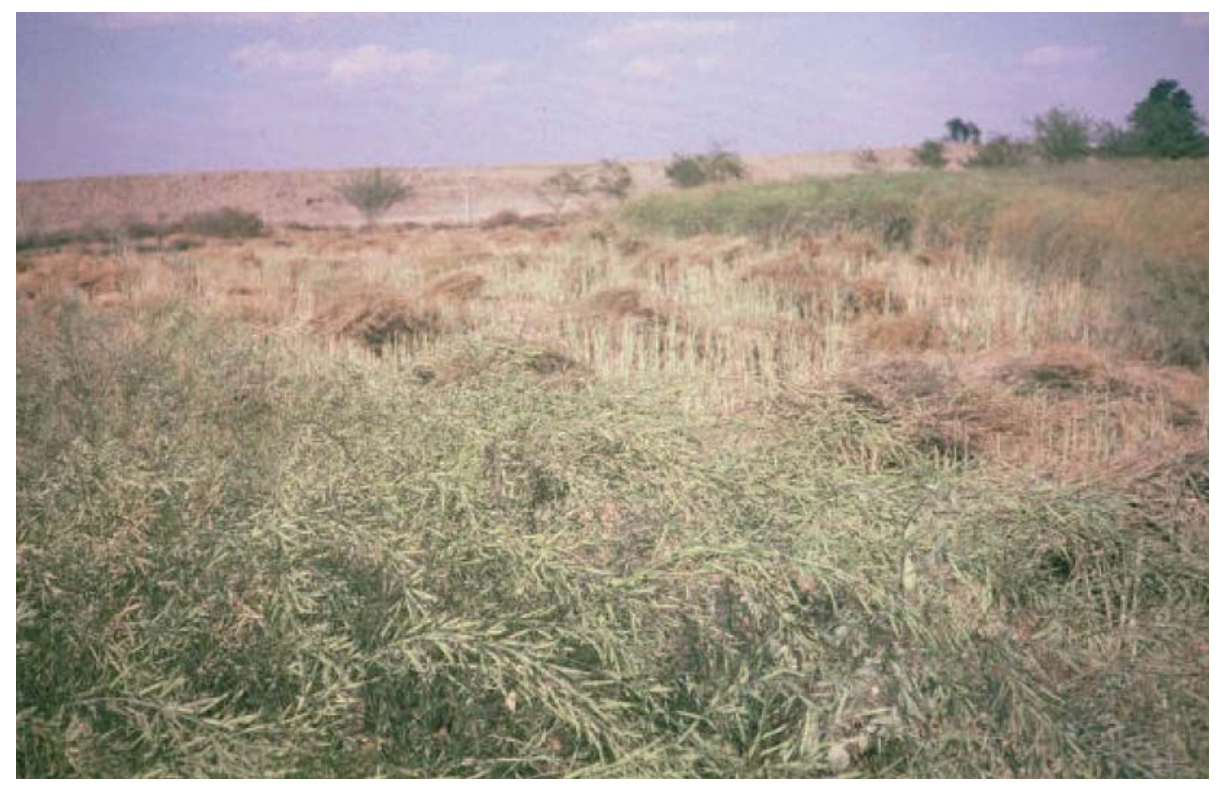

FIGURE 4: Innovative approach for mustard crop cultivation with saline irrigation on sandy desert at Cholistan (Pakistan). Ahmad, Farooq 2008.

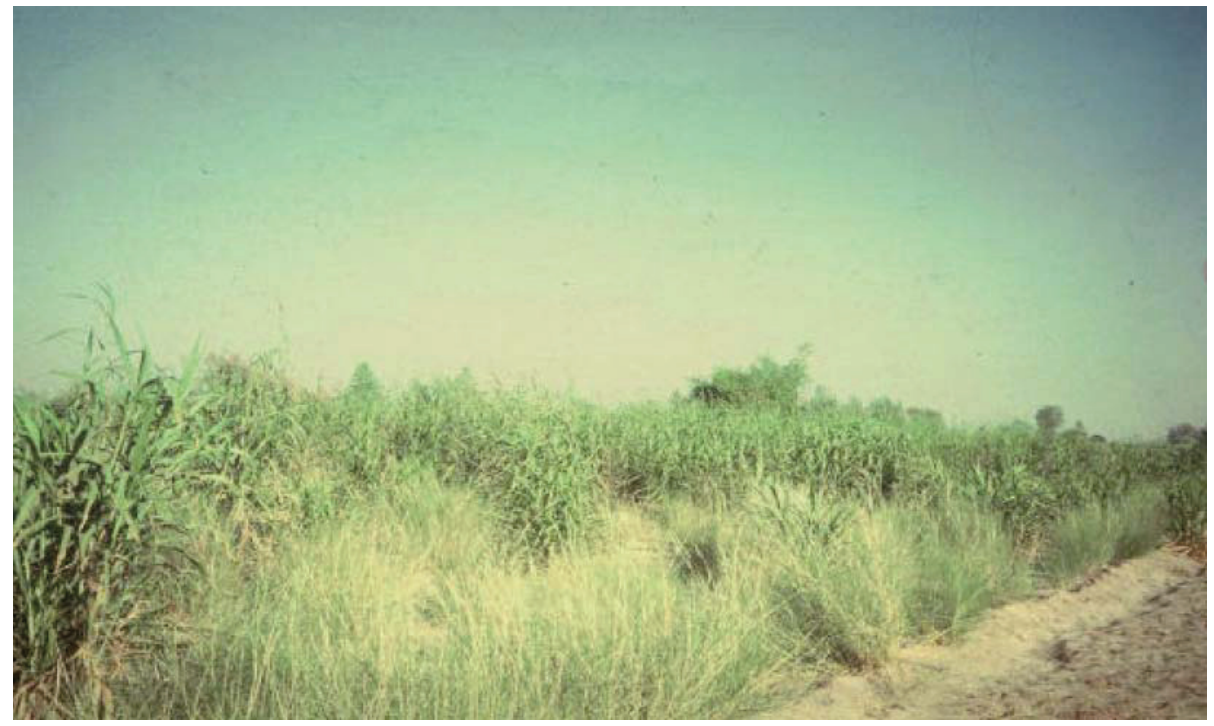

FIGURE 5: Innovative approach for development of grassland with saline irrigation on sandy desert at Cholistan (Pakistan). Ahmad, Farooq 2008.

The germination capacity of different varieties of tomato, ladyfinger (bhindi), spinach (palak), cowpea and zucchini (tori) at different levels $\mathrm{EC}_{\mathrm{e}} 3$ to $18 \mathrm{mmho} / \mathrm{cm}$ was studied in sand culture (PAMDU 1986). The germination was delayed and decreased with increased salinity. Significant vegetables were found to fall in the order of salt tolerance: Spinach $>$ Zucchini $>$ Cowpea $>$ Tomato $>$ Ladyfinger (Abdullah et al. 1990). The list of some salt tolerant grasses and forages cultivated in the Cholistan Desert by using saline water is given in TABLE 5. 
Leptochloa Fusca Cultivation for Utilization of Salt - affected Soil and Water Resources in Cholistan Desert Farooq Ahmad

TABLE 5: Salt tolerant plants cultivated in Cholistan Desert by using saline water

\begin{tabular}{|l|c|}
\multicolumn{1}{|c|}{ Forage Crop/Grass/Bush } & $\begin{array}{c}\text { Tolerance }\left(\mathrm{EC}_{\mathrm{e}} \square 10^{6}\right) \\
4000-18000\end{array}$ \\
\hline Alkali grass (Puccinellia airoides) & High \\
\hline Bermuda grass (Cymodon dactylon) & High \\
\hline Kallar grass (Leptochloa fusca) & High \\
\hline Salt grass (Distichlis stricta) & High \\
\hline Desert wheat grass (Agropyron cristatum) & High \\
\hline Barley (Hordium vulgare) & Hedium \\
\hline Rape (Brassica napus) & Medium \\
\hline Clover (Melilotus) & Medium \\
\hline Alfalfa (California common) & Medium \\
\hline Oats (Hay) & High \\
\hline Atriplex spp. & \\
\hline
\end{tabular}

Source: PADMU. - Pakistan Desertification Monitoring Unit (1986).

\section{CONCLUSION}

The growth factors such as easy propagation, high - spreading rate, colonizing ability, vigorous growth, yield, palatability, nutritional value, long term survival and high adaptability to environmental stress make L. fusca an excellent and versatile species that can be cultivated by using brackish water and salt - affected land of Cholistan for economic exploitation. The species has great promise for the economic utilization of sodic, high $\mathrm{pH}$, waterlogged and saline soils. Similarly, high saline - sodic water can be used for successful cultivation of $L$. fusca.

\section{ACKNOWLEDGEMENTS}

The author wishes to thank Dr. Mohammad Arshad, Cholistan Institute of Desert Studies, Islamia University Bahawalpur, Pakistan for providing technical assistance during the field study of Cholistan desert and valuable comments on a draft - version of this paper.

\section{REFERENCES}

ABDULlAH, M. Salt tolerance studies on Leptochloa Fusca, Ph.D. 1985. Dissertation (unpublished), University of Agriculture, Faisalabad, Pakistan,1985. p. 286.

ABDULlAH, M., AKRAM, M., KHAN, A.D.,
QURESHI, R.H. Internal water resources management by plants under various root environment stresses with special reference to kallar grass Leptochloa Fusca, In: NATIONAL SEMINAR ON WATER RESOURCES DEVELOPMENT AND ITS MANAGEMENT IN ARID AREAS, 6 - 8 October 1990, Quetta, Pakistan. Anais... Quetta, Pakistan, 1990.

ABDULLAH, M., QURESHI, R.H., AHMAD, N. Responses of Leptochloa Fusca to various types of substrate salinities. In: PAK. - US. BIOSALINE RESEARCH WORKSHOP, 22 - 26 September 1985, Karachi, Pakistan, 1986. Anais... Karachi, Pakistan, 1986. p.115 - 123.

AHMAD, F. Socio - economic dimensions and ecological destruction in Cholistan, Ph.D. 2002. Dissertation (unpublished), Department of Geography, University of Karachi, Pakistan, 2002.

AHMAD, F. Agro - pastoral systems in Cholistan, Pakistan Geographical Review, Vol.60 (2),2005. p. $65-69$.

AHMAD, F. Geoinformatics application to investigate agricultural potential in Cholistan desert, Journal of Food, Agriculture \& Environment, WFL Publisher, Finland, Vol.5(2), 2007. p. $310-314$.

AHMAD, F. Runoff farming in reducing rural poverty in Cholistan desert. Soc. nat. (Online), 
Uberlândia, v. 20, n. 1, jun. 2008 . Disponível em $\quad<$ http://www.scielo.br/scielo.php?script=sci_ arttext\&pid=S1982-45132008000100012\&lng $=$ pt\& nrm=iso $>$. Acesso em 18 fev. 2010. DOI: $10.1590 /$ S1982-45132008000100012.

AHMAD, F.; GULZAR, F.; SHIRAZI, S. A.; FAROOQ, S.; ALI, Z. Leptochloa Fusca: A high yielding grass for utilization of salt - affected soil and water resources in Cholistan, In: FOURTH INTERNATIONAL CONFERENCE ON LAND DEGRADATION, 12 - 17 September 2004, Murcia, Spain. Anais... Murcia, Spain, 2004. p.434.

AKHTAR, J., R.A. WAHEED, K.A. MALIK, M.I. Haq. Effect of kallar grass growth on water transmission characteristics of salt - affected lands, In: FIRST NATIONAL CONGRESS ON SOIL SCIENCES, 6 - 8 October 1985, Lahore, Pakistan. Anais... Lahore, Pakistan, 1985. p.393 - 400.

ARSHAD, M., ALTAF - UR - REHMAN RAO, AKBAR, G. Cholistan desert in a state of flux, UNEP: Desertification Control Bulletin, 26, 1995. p. $55-58$.

FAO/ADB. Cholistan area development project, Report No. 59/53 ADB - PAK 58 (Final version), Food and Agriculture Organization (FAO), Rome, Italy. 1993.

HAQ, M., KHAN, M.F.A. Reclamation of saline and alkaline soil by growing kallar grass, The Nucleus, Vol.8 (4), 1971. p. 139 - 144.

JOSHI, Y.C., QADIR, A., SHARMA, S.K. Sequential changes in germination, root and shoot growth and anatomical characters of halophytes and glycophytes, Annual report for 1980, Central Soil Salinity Research Institute, Karnal, India, 1981. p.94 $-97$.

JOWKAR, F., KHAN, M. AJMAL. Socio-economic dimensions of resource management in Cholistan, Institute for Development Anthropology (IDA), Binghamton, New York. 1996.
KHAN, A.D., AKRAM, M., ABDULLAH, M. Rainwater harvesting in Cholistan desert, In: NATIONAL SEMINAR ON WATER RESOURCES DEVELOPMENT AND ITS MANAGEMENT IN THE ARID AREAS, 6 - 8 October 1990, Quetta, Pakistan. Anais... Quetta, Pakistan, 1990. p. 59-80.

KUMAR, A.D., ABROL, I.P. DARGAN, K.S. Karnal grass grows well in sodic soils, Indian Farming, Vol.30 (3), 1980. p. $14-15$.

MALIK, K.A.; ZAFAR,Y.; HUSSAIN, A. (1980). Nitrogenase activity in the rhizosphere of kallar grass Diplachne Fusca, Biologia, Vol.26 (1 - 2), 1980. p. $107-112$.

MALIK, K.A., ASLAM, Z., NAQVI, M. Kallar grass - a plant for saline lands, Nuclear Institute for Agriculture and Biology (NIAB), Faisalabad, Pakistan, 1986. p.93.

PAMDU. Desertification process in Cholistan desert, PCRWR Publication No. PADMU 7/86, 1986. p.155.

QURESHI, R.H., ASLAM, M., ABDULLAH, M., PITMAN, M.G. Diplachne Fusca: An Australian salt tolerant grass used in Pakistan, Journal of Australian Institute for Agricultural Science, Vol.48 (4), 1982. p. $195-199$.

SANDHU, G.R. Sustainable agriculture: A Pakistan National Conservation Strategy Sector Paper No. 2, Environment and Urban Affairs Division, Government of Pakistan and IUCN - The World Conservation Union, Pakistan. 1993.

SANDHU, G.R., ASLAM, Z., SATTAR, A., QURESHI, R.H., N. AHMAD, R.G. Wyn Jones. The effect of salinity on the yield and composition of Diplachne Fusca (kallar grass) plant, Cell Environ, Vol.4, 1981.p. $171-181$.

ZAFAR, Y.; MALIK, K.A. Photosynthetic system of Leptochloa Fusca (L.) Kunth, Pakistan Journal of Botany, Vol.16 (2), 1984. p. 109 - 116. 